\title{
An outbreak of cyclosporiasis in 1996 associated with consumption of fresh berries - Ontario
}

\author{
DG Manuel MD MSc ${ }^{1,2,3}, \mathrm{~S}$ Neamatullah $\mathrm{MBBS}_{\mathrm{MPH}}{ }^{1,5}$, R Shahin $\mathrm{MD} \mathrm{MHSc}{ }^{2,3}$, D Reymond $\mathrm{MD}^{4}$, \\ J Keystone MD MSc(CTM) ${ }^{4}$, J Carlson MBBS DCH ${ }^{5}, \mathrm{C}$ Le Ber DVM ${ }^{5}, \mathrm{BL}^{2}$ Herwaldt MD MPH ${ }^{6}, \mathrm{DH}$ Werker MD MHSc ${ }^{1}$
}

DG Manuel, S Neamatullah, R Shahin, et al. An outbreak of cyclosporiasis in 1996 associated with consumption of fresh berries - Ontario. Can J Infect Dis 2000;11(2):86-92.

BACKGROUND: A large foodborne outbreak of cyclosporiasis occurred in North America in 1996. An index cluster of cases associated with a catered event on May 11, 1996, in Ontario sparked the recognition of this outbreak in Canada. OBJECTIVES: To describe the Ontario experience with the North American outbreak of cyclosporiasis in 1996.

PATIENTS AND METHODS: Public health units investigated the index and subsequent event-associated clusters. Investigations included retrospective cohort studies of clusters, traceback of suspect foods and a case-control study of sporadic cases. These activities, coordinated with those in the United States, were part of an international investigation. RESULTS: In Ontario, 232 cases of cyclosporiasis (20 laboratory-confirmed and 72 clinically defined cases associated with seven events plus 140 additional laboratory-confirmed sporadic cases) were identified between May 1 and July 30, 1996. For the index cluster, a strawberry flan with raspberries and blueberries was the only significant exposure (relative risk 2.16, $\mathrm{P}=0.02$ ). Fresh berries were served at all seven events associated with clusters of cases. Raspberries were definitely served at three events, possibly served at three events, and not served at one event. Only imported berries were available in Ontario in May 1996, when initial clusters and sporadic cases were identified. The raspberries served at the two events with well documented traceback data came from Guatemala. Univariate analyses of the matched case-control study demonstrated that illness was associated with consumption of raspberries (matched odds ratio $21.0,95 \%$ CI 3.48 to 448 ) and strawberries (matched odds ratio $28.5,95 \% \mathrm{CI} 4.02$ to 478 ). Further evidence amassed by the international investigation compellingly implicated Guatemalan raspberries as the vehicle of the outbreak.

CONCLUSION: Cyclosporiasis may be acquired domestically from the consumption of contaminated produce. The scope and vehicle of this international foodborne outbreak were recognized through a coordinated public health response.

Key Words: Canada; Cyclosporiasis; Cyclospora cayetanensis; Foodborne outbreak

Pour le résumé, voir page suivante

\footnotetext{
${ }^{1}$ Field Epidemiology Training Program, Laboratory Centre for Disease Control, Health Canada, Ottawa; ${ }^{2}$ Department of Public Health Science, University of Toronto; ${ }^{3}$ North York Public Health Department; ${ }^{4}$ Tropical Disease Unit, Toronto Hospital; ${ }^{5}$ Ontario Ministry of Health, Public Health Branch, Toronto, Ontario; ${ }^{6}$ Division of Parasitic Diseases, National Center for Infectious Diseases, Centers for Disease Control and Prevention, Atlanta, Georgia

Correspondence and reprints: Dr Denise Werker, Associate Director, Field Epidemiology Training Program, Laboratory Centre for Disease Control, Tunney's Pasture 0602B, Ottawa, Ontario K1A OL2. Telephone 613-954-5790,fax 613-954-6028, e-mail Denise_Werker@hc-sc.gC.ca
} 


\section{Éclosion de cyclosporiasis en 1996, associée à la consommation de baies fraîches - Ontario}

CONTEXTE : Une importante éclosion de cyclosporiasis d'origine alimentaire est survenue en Amérique du Nord en 1996. L'existence d'un agrégat de cas primaires, associée à un événement avec traiteurs le 11 mai 1996, en Ontario, a déclenché l'investigation relative à l'éclosion de la maladie au Canada.

OBJECTIF : Décrire l'expérience de l'Ontario relativement à l'éclosion de cyclosporiasis en Amérique du Nord en 1996.

PATIENTS ET MÉTHODE : Les unités de soins ont investigué l'agrégat de cas primaires ainsi que les agrégats subséquents associés à des événements. L'investigation comprenait des études rétrospectives de cohortes dans les agrégats, le retraçage des aliments douteux et une étude cas/témoins de cas sporadiques. Ces activités, coordonnées à celles qui étaient en cours aux États-Unis, faisaient partie d'une investigation internationale.

RÉSULTATS : Deux cent trente-deux cas de cyclosporiasis ( 20 cas confirmés en laboratoire, 72 cas cliniques associés à sept événements et 140 autres cas sporadiques confirmés en laboratoire) ont été signalés en Ontario entre le $1^{\mathrm{er}}$ mai et le 30 juillet 1996. En ce qui concerne l'agrégat de cas primaires, une tarte aux fraises, avec framboises et bleuets, était le seul élément significatif d'exposition à un produit (risque relatif : 2,$16 ; \mathrm{P}=0,02$ ). Dans les sept événements associés aux agrégats de cas, on avait servi des baies fraîches. Des framboises ont certainement été servies dans trois événements, probablement dans trois autres et pas du tout dans le dernier. On ne disposait, en mai 1996 en Ontario, que de baies importées quand sont apparus les premiers agrégats de cas et les cas sporadiques. On a pu retracer, grâce à des données bien documentées, l'origine des framboises servies à deux des événements; elles provenaient du Guatemala. Les analyses à une seule variable de l'étude cas/témoins appariés ont révélé que la maladie était associée à la consommation de framboises (risque relatif apparié :21,0; IC à $95 \%$ : 3,48 à 448) et de fraises (risque relatif apparié :28,5; IC à $95 \%: 4,02$ à 478). D'autres données recueillies au cours de l'investigation internationale ont immanquablement ciblé les framboises provenant du Guatemala comme le véhicule de l'éclosion.

CONCLUSION : Le cyclosporiasis contracté au Canada peut avoir comme origine la consommation de produits contaminés. C'est grâce à un effort concerté des autorités en santé publique qu'on a pu déterminer l'étendue et le véhicule de cette éclosion internationale de cyclosporiasis.

$\mathrm{C}^{\mathrm{s}}$ yclosporiasis is caused by ingestion of oocysts of Cyclospora cayetanensis, a parasite which was first recognized in the late 1970 s (1). The clinical picture of cyclosporiasis can be indistinguishable from that of giardiasis, cryptosporidiosis and isosporiasis. The main symptom is watery diarrhea that occurs in a relapsing, cyclical pattern, lasting for several days to weeks; it is often associated with weight loss and fatigue. In immunocompromised hosts, especially those with AIDS, the duration and severity of illness may be increased (2). The recommended treatment for cyclosporiasis is a seven-day course of trimethoprim/sulphamethoxazole, but patients with AIDS may require both longer courses of therapy and maintenance therapy $(2,3)$.

Cyclospora oocysts, measuring 8 to $10 \mathrm{~m}$ in diameter, are recognized as nonrefractile spheres (containing refractile globules) on light microscopic examination of wet preparations of stool. With modified acid-fast staining, some oocysts may stain deep red, others may stain pink and still others may remain unstained as glassy, membranous oocysts (4).

Foodborne and waterborne transmission are now well established (5-7). Before 1995, outbreaks were infrequent and usually associated with waterborne transmission $(5,6)$. In Canada before 1996, case reports were associated with travellers returning from developing countries (8). In Ontario, Brennan et al (9) reported an estimated prevalence of 0.5 cases/1000 stool examinations based on a survey examining 80,000 stool samples submitted to three parasitology laboratories from June 1993 through June 1995 (9).

In May 1996, the North York Public Health Department in Ontario was notified by a local primary care physician of several cases of cyclosporiasis among guests who had attended a wedding reception on May 11, 1996. Simultaneously, another cluster of cases was being investigated in Houston, Texas; and several state health departments in the United States reported an increased number of cases of cyclosporiasis to the Centers for Disease Control and Prevention, Atlanta, Georgia (CDC). These clusters and sporadic cases were ultimately recognized as part of a North American outbreak of cyclosporiasis for which preliminary investigations implicated both strawberries and raspberries. This paper describes the Ontario experience with the North American outbreak of cyclosporiasis in 1996.

\section{PATIENTS AND METHODS}

The index Ontario cluster was investigated by the North York Public Health Department, Toronto, Ontario (10). Initially, cases were ascertained and an environmental inspection of the implicated venue was conducted. Thereafter, a retrospective cohort study examined food and water consumption by attendees. For this first cluster, a case was defined as having three or more unexplained loose or watery bowel movements/day for three consecutive days, or a stool specimen positive for cyclospora oocysts.

Further case finding and cluster identification: Laboratories do not routinely look for cyclospora oocysts in stools submitted for 'ova and parasite' testing. To facilitate the diagnosis of cases and to enhance surveillance, the Ontario Ministry of Health, Toronto, Ontario requested that laboratories in Ontario report when cyclospora oocysts were identified in stool specimens and that public health units interview all laboratoryconfirmed cases with a structured questionnaire. The sporadic case questionnaire gathered information about demographics, travel history outside Ontario and North America, and consumption of strawberries, raspberries, blackberries, blueberries and other fresh produce during the two weeks before the onset of symptoms.

A sporadic case was defined as a person with a stool specimen positive for cyclospora oocysts during May 1 through July 30, 1996 who did not travel overnight outside North America in the four weeks before illness and who was not as- 


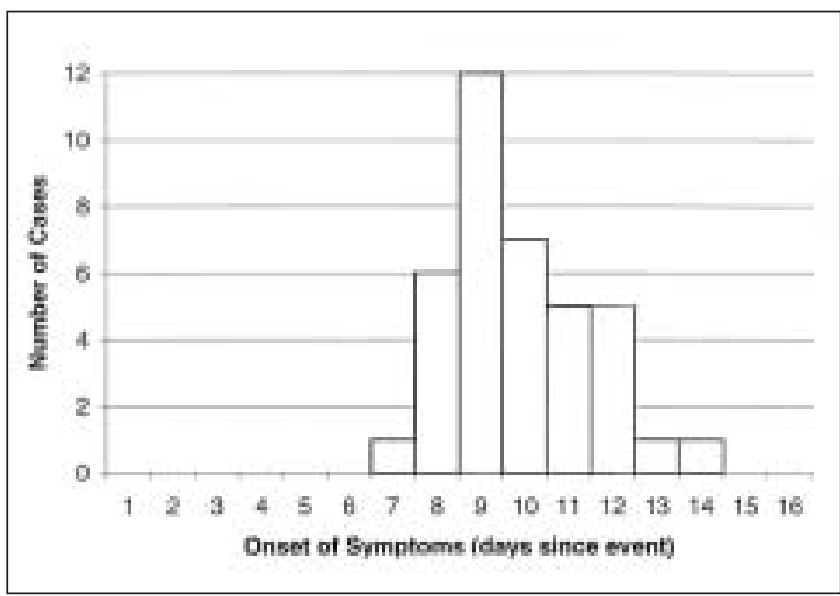

Figure 1) Epidemic curve for the index Ontario cyclosporiasis cluster, event data, May 11, 1996 ( $n=35$ cases)

sociated with a cluster. Clinical cases associated with clusters were defined in a similar manner as for the index cluster. Clusters were defined as two or more cases associated with a common event, with at least one case being laboratory-confirmed by a reference laboratory (Ontario Provincial Laboratory, Toronto, Ontario or $\mathrm{CDC}$ ). The local public health unit(s) performed cluster investigations. Provincial and territorial epidemiologists across Canada were notified about the investigations in Ontario and the United States.

Traceback investigations: The Canadian Food Inspection Agency, Ottawa, Ontario, Health Canada and the public health inspectors of the specific health units carried out traceback investigations with assistance from the Ontario Ministry of Health. Only imported berries were available for sale in Ontario when the initial events occurred. Airway bill numbers of imported berries likely served at the implicated events were provided to the CDC and United States Food and Drug Administration (FDA) to trace the sources of the berries to the exporters and farms that contributed to specific shipments. Traceback activities in Canada were coordinated with the extensive activities in the United States. A well documented traceback of produce was considered one that confirmed verbally and in writing (eg, through copies of invoices) all steps from consumers back to farms (7).

Case-control study: A matched case-control study was conducted to determine further whether consumption of berries was associated with cyclospora infection in Ontario. Sporadic cases were included if they were Ontario residents at least age 18 years and had an onset of symptoms by July 1,1996 . Sporadic cases were excluded if other enteric pathogens were identified on stool examination.

Potential neighbourhood and age-matched controls were interviewed by telephone. Inclusion criteria for controls were no gastrointestinal illness on or after May 1, 1996, no foreign travel during the four weeks before onset of illness of the matched case and no more than three nights spent outside of Ontario during the two weeks before onset of illness of the matched case.

A structured questionnaire gathered information about
TABLE 1

Food exposures and risk of developing illness in the index cluster in an outbreak of cyclosporiasis in Ontario in 1996

\begin{tabular}{lclcc}
\hline Food item* & $\begin{array}{c}\text { Attack rate in } \\
\text { the exposed }^{+}\end{array}$ & $\begin{array}{c}\text { Attack rate in } \\
\text { unexposed }\end{array}$ & $\begin{array}{c}\text { Relative } \\
\text { risk }\end{array}$ & P \\
\hline $\begin{array}{l}\text { Strawberry flan } \\
\text { with raspberries } \\
\text { and blueberries }\end{array}$ & $0.81(30 / 37)$ & $0.38(3 / 8)$ & 2.16 & $0.02^{\ddagger}$ \\
$\begin{array}{l}\text { Caesar salad } \\
\text { Chulent }\end{array}$ & $0.71(24 / 34)$ & $0.50(5 / 10)$ & 1.42 & $0.27^{\ddagger}$ \\
$\quad 0.77(20 / 26)$ & $0.64(14 / 22)$ & 1.20 & 0.31 \\
$\quad$ cooked beef) & & & & \\
Corned beef & $0.77(17 / 22)$ & $0.65(17 / 26)$ & 1.18 & 0.37 \\
Chicken & $0.83(15 / 18)$ & $0.67(20 / 30)$ & 1.25 & $0.32^{\ddagger}$ \\
Egg salad & $0.71(15 / 21)$ & $0.71(20 / 28)$ & 1.00 & 1.00 \\
Water & $0.78(14 / 18)$ & $0.62(16 / 26)$ & 1.26 & 0.26 \\
Tea & $0.71(12 / 17)$ & $0.70(21 / 30)$ & 1.01 & 0.97 \\
Tomato salad & $0.67(4 / 6)$ & $0.73(29 / 40)$ & 0.92 & $1.00^{\ddagger}$ \\
\hline
\end{tabular}

*Food items shown include all the fresh produce and the cooked items with highest relative risk and statistical significance; ${ }^{\dagger}$ People who recalled eating the food item. The food items are ranked by frequency of exposure in cases. ${ }^{*}$ Fisher's exact p-value

consumption of fresh berries and other fresh fruits and vegetables, domestic water supply and water consumption, and exposures to domestic animals and soil. Cases and their matched controls were questioned about exposures during the two weeks before the relevant case's onset of illness. Cases and controls were interviewed from July 4 to July 27, 1996.

Statistical analysis: For analyses of the clusters of cases, univariate relative risks were calculated for exposure variables, and two-tailed P values were computed with ${ }^{2}$ test or, if appropriate, Fisher's exact test. For the case-control study univariate analyses were performed in EPI INFO 6.04 (CDC, Atlanta, Georgia). Continuous variables were dichotomized into high and low categories by the median. Mantel-Haenszel matched odds ratios and confidence intervals determined by the exact $95 \%$ percent mid-P limits. Conditional logistic regression was performed in LogXact (Cytel Corp, Cambridge, Massachusetts).

\section{RESULTS}

Event-associated clusters: In the index cluster, 35 of the 49 guests became ill (attack rate $71 \%$ ). The median incubation period was eight days (range six to 13 days). Only symptomatic persons submitted stool specimens for laboratory testing, of whom 13 (59\%) of the 22 were positive for cyclospora oocysts. The epidemic curve (Figure 1) was consistent with a pointsource outbreak. No secondary cases were identified. Analyses of food exposures (Table 1) showed that the strawberry flan with raspberries and blueberries was the only food item significantly associated with illness (relative risk $2.16, \mathrm{P}=0.02$ ).

By the end of July 1996, enhanced cluster surveillance identified six additional event-associated clusters of cases. All seven clusters are summarized in Table 2 . The events occurred from May 11 through June 14, 1996. Of the 213 persons attending these seven events, $164(77 \%)$ were interviewed. Among these, 20 laboratory-confirmed and 72 additional clinically defined cases of cyclosporiasis were identified. The 
TABLE 2

Summary of the seven clusters of cyclosporiasis in Ontario, 1996 (by event date)

\begin{tabular}{|c|c|c|c|c|c|c|c|c|c|}
\hline Event \# & $\begin{array}{c}\text { Date of } \\
\text { event }\end{array}$ & Description & Attendees & $\begin{array}{c}\text { Attack rate } \\
\text { (cases/attendees } \\
\text { [interviewed]) }\end{array}$ & $\begin{array}{l}\text { Number of } \\
\text { laboratory- } \\
\text { confirmed } \\
\quad \text { cases }\end{array}$ & $\begin{array}{c}\text { Berry } \\
\text { consumption }\end{array}$ & $\begin{array}{c}\text { Raspberries } \\
\text { served at } \\
\text { event }\end{array}$ & $\begin{array}{c}\text { Well } \\
\text { documented } \\
\text { raspberry } \\
\text { (blackberry) } \\
\text { traceback }\end{array}$ & $\begin{array}{c}\text { Relative risk } \\
\text { and } P\end{array}$ \\
\hline 1 & May 11 & $\begin{array}{l}\text { Wedding } \\
\text { (North York) }\end{array}$ & 49 & $71 \%(35 / 49)$ & 13 & $\begin{array}{l}\text { Strawberry flan } \\
\text { with raspberries } \\
\text { and blueberries }\end{array}$ & $\begin{array}{c}\text { Definitely } \\
\text { served }\end{array}$ & $\begin{array}{c}\text { Yes, } \\
\text { Guatemalan } \\
\text { farms }\end{array}$ & $\begin{array}{c}2.16 \\
P=0.02\end{array}$ \\
\hline 2 & May 11 & $\begin{array}{c}\text { Dinner } \\
\text { party } \\
\text { (Toronto) }\end{array}$ & 20 & $75 \%(12 / 16)$ & 1 & $\begin{array}{c}\text { Fresh } \\
\text { raspberries and } \\
\text { blueberries }\end{array}$ & $\begin{array}{c}\text { Definitely } \\
\text { served }\end{array}$ & No & NA \\
\hline 3 & May 15 & $\begin{array}{c}\text { Soccer team } \\
\text { meal } \\
\text { (Ottawa) }\end{array}$ & 14 & $50 \%(6 / 12)$ & 1 & $\begin{array}{c}\text { Fruit salad with } \\
\text { strawberries } \\
\text { and } \\
\text { blackberries }\end{array}$ & Not served & $\begin{array}{c}\text { Yes, } \\
\text { Guatemalan } \\
\text { farm } \\
\text { (blackberries) }\end{array}$ & $\begin{array}{c}\mathrm{RR}=\text { undefined } \\
\mathrm{P}=0.002\end{array}$ \\
\hline 4 & May 17-19 & $\begin{array}{c}\text { Private } \\
\text { parties } \\
\text { (North York) }\end{array}$ & 50 & $31 \%(8 / 26)$ & 1 & $\begin{array}{c}\text { Chocolate } \\
\text { dipped and } \\
\text { plain } \\
\text { strawberries, } \\
\text { likely other } \\
\text { berries }\end{array}$ & $\begin{array}{c}\text { Probably } \\
\text { served }\end{array}$ & No & NA \\
\hline 5 & May 28 & $\begin{array}{l}\text { Business } \\
\text { luncheon } \\
\text { (Toronto) }\end{array}$ & 32 & $52 \%(11 / 21)$ & 1 & $\begin{array}{c}\text { Fresh fruit flan } \\
\text { (with various } \\
\text { berries) }\end{array}$ & $\begin{array}{c}\text { Probably } \\
\text { served }\end{array}$ & No & NA \\
\hline 6 & June 1 & $\begin{array}{c}\text { Bridal } \\
\text { shower } \\
\text { (Toronto) }\end{array}$ & 22 & $55 \%(12 / 22)$ & 2 & $\begin{array}{c}\text { Cake garnished } \\
\text { with } \\
\text { strawberries, } \\
\text { raspberries and } \\
\text { blueberries }\end{array}$ & $\begin{array}{c}\text { Definitely } \\
\text { served }\end{array}$ & $\begin{array}{c}\text { Yes, } \\
\text { Guatemalan } \\
\text { farms }\end{array}$ & $\begin{array}{c}4.2 \\
P=0.02\end{array}$ \\
\hline 7 & June 9-14 & $\begin{array}{c}\text { Business } \\
\text { seminar } \\
\text { (Caledon) }\end{array}$ & 26 & $56 \%(10 / 18)$ & 1 & $\begin{array}{c}\text { Fruit salad with } \\
\text { various berries }\end{array}$ & $\begin{array}{c}\text { Probably } \\
\text { served }\end{array}$ & No & NA \\
\hline
\end{tabular}

NA Not applicable, food exposure data were not obtained from the attendees

overall attack rate was 56\% (94 of 168). Cluster-specific attack rates ranged from $30 \%$ to $71 \%$, and the median of the clusterspecific incubation periods was eight days. The incubation period for all 94 individual cases varied from two to 14 days.

For all events, food recall histories indicated that various mixtures of raspberries, strawberries, blackberries and blueberries were served. Raspberries were definitely not served at only one event (\#3), an event at which blackberries from Guatemala were served. The tracebacks that were well documented demonstrated that raspberries served at events \#1 and \#6 originated from the same Guatemalan exporter and the blackberries from event \#3 originated from another Guatemalan exporter. Although tracebacks for the other events did not fulfill the criteria of being well documented, only berries from outside Canada were available during the outbreak period.

Sporadic cases: From May 1, 1996, through July 30, 1996, 140 sporadic cases were reported to the Ontario Ministry of Health. For the 131 cases for whom sex and age information was available, the median age was 46 years (range 12 to 85 years) and $47 \%$ $(n=62)$ were male. Public health unit personnel completed questionnaires for 74 sporadic cases. No cases were hospitalized, nor were there any reported deaths. The proportion of sporadic cases who, during the two weeks before illness onset, reportedly ate raspberries was $42 \%$ (30 of 72 ), strawberries $78 \%$ (56 of 72 ), blueberries $24 \%$ (17 of 70 ) and blackberries $7 \%$ (five of 69 ). Case-control study: Twenty-six of the 140 sporadic cases and 52 controls were interviewed for the case-control study. Thirty-eight per cent $(n=10)$ of the cases and $33 \%(n=17)$ of controls were men. The median ages of the cases and controls were 42 years (range 19 to 76 years) and 41 years (range 18 to 87 years), respectively. Cases were significantly more likely than their matched controls to have completed postsecondary education (matched odds ratio $[\mathrm{MOR}]=7.33 ; 95 \% \mathrm{CI} 1.89$ to 28.0 ).

For cases, the predominant symptoms were diarrhea (96\%), fatigue (96\%), weight loss (96\%), increased gas or bloating (88\%), abdominal pain (77\%), nausea $(61 \%)$, headache $(54 \%)$ and fever (38\%). The median weight loss was $3 \mathrm{~kg}$ (maximum $8.0 \mathrm{~kg}$ ). The onsets of illness were from May 16 to June 26, 1996. All 26 cases consulted physicians for their illness; none were hospitalized. Trimethoprim/sulphamethoxazole was prescribed to $81 \%$ of the cases. The median duration of diarrhea was 13 days (range zero to 28 days), not accounting for whether the cases had been treated. Three cases reported having a medical condition affecting their immune system, but none reported having HIV infection, organ transplantation, diabetes or inflammatory bowel disease, or taking oral steroid medication. Five cases reported taking antacids, and two re- 
TABLE 3

Results of the matched case-control study (cases 26; controls 52) in an outbreak of cyclosporiasis in Ontario in 1996

\begin{tabular}{|c|c|c|c|c|}
\hline Variable & $\begin{array}{l}\text { Cases } \\
\text { n (\%) }\end{array}$ & $\begin{array}{c}\text { Controls } \\
\text { n (\%) }\end{array}$ & Matched odds ratio & $95 \% \mathrm{Cl}$ \\
\hline \multicolumn{5}{|l|}{ Univariate analysis } \\
\hline Completed postsecondary education & $21(81)$ & $23(44)$ & 7.3 & $1.89-28.0$ \\
\hline Strawberries & $24(92)$ & $19(36)$ & 28.5 & $4.02-478$ \\
\hline Cantaloupes & $17(65)$ & $21(40)$ & 3.8 & $1.21-13.6$ \\
\hline Raspberries & $11(42)$ & $2(4)$ & 21.0 & $3.48-448$ \\
\hline Blueberries & $8(31)$ & $4(8)$ & 6.5 & $1.38-44.8$ \\
\hline Peaches & $5(19)$ & $13(25)$ & 0.7 & $0.18-2.31$ \\
\hline Blackberries & $3(12)$ & 0 & Undefined & 0.82-infinity \\
\hline Fruit consumption more than one serving/day & $12(46)$ & $16(31)$ & 0.9 & $0.34-2.69$ \\
\hline \multicolumn{5}{|l|}{ Place of fruit purchase } \\
\hline Supermarket & $20(77)$ & $40(77)$ & 1.0 & $0.33-3.36$ \\
\hline Street vendor & $3(12)$ & $2(4)$ & 3.0 & $0.45-25.2$ \\
\hline Farmer's market & $3(12)$ & $5(10)$ & 1.2 & $0.22-6.21$ \\
\hline Green grocer & $10(38)$ & $13(25)$ & 2.4 & $0.66-5.55$ \\
\hline Any raw vegetables & $23(88)$ & $46(88)$ & 1.2 & $0.25-9.30$ \\
\hline Raw vegetable consumption more than one serving/day & $5(21)$ & $18(35)$ & 0.5 & $0.12-1.84$ \\
\hline Tap water more than two glasses/day & $9(36)$ & $29(55)$ & 0.5 & $0.17-1.21$ \\
\hline Any untreated drinking water & $2(8)$ & $6(12)$ & 0.6 & $0.08-3.38$ \\
\hline Pets at home & $13(50)$ & $21(40)$ & 1.4 & $0.56-3.81$ \\
\hline \multicolumn{5}{|l|}{ Multivariate analysis } \\
\hline Strawberries & & & 13.8 & 2.35-infinity* \\
\hline Raspberries & & & 6.3 & $0.86-277^{*}$ \\
\hline Completed postsecondary education & & & 5.3 & 0.77 -infinity* \\
\hline
\end{tabular}

*Exact Cl

ported taking ulcer medication. Six patients had made overnight trips outside Ontario but within North America.

All cases and $96 \%(n=50)$ of the controls reported eating fresh fruit during the two-week exposure period. All cases and $98 \%(n=51)$ of the controls reported that they usually washed fruit before they ate it. There were no differences between cases and their matched controls in the number of servings of fresh fruit or raw vegetables consumed daily. In the univariate analyses, illness was associated with consumption of strawberries $(\mathrm{MOR}=28.5,95 \% \mathrm{CI} 4.02$ to 478$)$, raspberries $(\mathrm{MOR}=21.0$, $95 \% \mathrm{CI} 3.48$ to 448 ), blackberries (MOR=undefined, $95 \% \mathrm{CI}$ 0.82 to infinity) and blueberries (MOR $=6.5,95 \%$ CI 1.38 to 44.8). Illness was not associated with consumption of other fruits, place of fruit purchase, consumption of tap water or exposure to untreated water or animals. Analyses are summarized in Table 3 .

Consumption of strawberries was the only statisically significant risk factor in a conditional logistics regression model that included all types of berry consumption and education. The final model excluded blueberries and blackberries, in part, because of the infrequent consumption of these berries.

\section{DISCUSSION}

By the end of August 1996, 1465 cases of cyclosporiasis were reported in North America (740 sporadic and 725 cases related to 55 clusters) (7). Preliminary investigations suggested a possible common source for this outbreak. Although several berries including strawberries were initially suspect,
Guatemalan raspberries were ultimately implicated. This conclusion was based on the strength of the cumulative evidence gathered in many jurisdictions, thus highlighting the importance of the coordinated multiagency response led by the CDC.

Several key factors were crucial to the initial identification and investigation of this outbreak. A family physician was responsible for reporting the first cluster of cases of cyclosporiasis in Ontario. Subsequently, the municipal public health unit notified provincial public health authorities when local investigations raised concerns of a widespread and ongoing outbreak. The additional event-associated clusters and sporadic cases in Ontario were recognized in part because Ontario laboratories and health units received specific directions to facilitate diagnosis and enhance surveillance. The initial responses from the local primary and public health systems are testimony to their important role in surveillance and control of communicable diseases, including emerging infectious diseases.

The different components of the outbreak investigation in Canada (cohort cluster investigations, a case-control study of sporadic cases, and the traceback of berries to a common source) and the necessity of combining evidence from investigations in other jurisdictions, each have potential strengths and limitations. An important limitation of the Ontario casecontrol study was potential recall bias from media attention on strawberries. Patients with cyclosporiasis may have been more likely to recall eating strawberries than other produce, thereby increasing the likelihood of an observed association. In several American case-control studies that were performed 
earlier than the Ontario study, consumption of fresh raspberries was most strongly associated with illness (7). The potential for recall bias was less likely in the cluster investigations compared with the case-control study because persons were interviewed earlier and specifically about food eaten at a single event. At these events, however, the berry items included mixtures of berries and only three of seven clusters had well documented food histories. Tracing food to a contaminated common source can potentially provide strong direct evidence of causal association. However, tracebacks of fresh produce in general, and berries in particular, are often difficult to perform. Only two of the six cluster-associated events (events \#1 and \#6) in Ontario at which raspberries were definitely or probably served had well documented traceback data.

Raspberry exports from Guatemala to Canada are routed via the United States and occur primarily in the spring and fall. From March 23 to July 7, 1996, Guatemalan raspberries represented approximately $10 \%$ of the $88,565 \mathrm{~kg}$ of raspberries imported into Canada (personal communication, Horticulture Section, Agriculture and Agri-Food Canada, 1996). Of the Guatemalan raspberries imported during this period, $86 \%$ were imported from May 1 to June 22 when the cluster-associated events occurred. During this period, Guatemalan raspberries were not imported into British Columbia, Manitoba, Saskatchewan or the Atlantic Provinces and no increase in cases of cyclosporiasis was identified in these provinces. From May 1 to June 22, 1996, 79\% of the Guatemalan raspberries were imported into Quebec, where only one cluster and a few sporadic cases of cyclosporiasis were reported, whereas only $20 \%$ were imported into Ontario. Enhanced surveillance, availability of laboratory diagnostic testing and uneven distribution of contaminated raspberries could have contributed to the burden of disease identified in Ontario.

After the outbreak in 1996, Guatemalan berry growers voluntarily introduced control measures that focused on improving sanitary conditions and water quality on individual farms (11). Even so, in the spring of 1997, a cyclosporiasis outbreak in North America was associated with Guatemalan raspberries (11); during this time, raspberries were imported from only those farms classified by the Guatemalans as low risk. In 1997, outbreaks of cyclosporiasis in the United States were also associated with consumption of mesclun lettuce and fresh basil (12). In the spring of 1998, a cyclosporiasis outbreak associated with Guatemalan raspberries was identified in the Toronto area but not elsewhere $(13,14)$. Until June 9 , 1998, raspberries from low risk farms continued to be imported into Canada; no Guatemalan raspberries were imported into the United States in the spring of 1998. The mode of raspberry contamination has not been identified for any of these outbreaks. As of December 1999, the fall and winter crop (November and December) of Guatemalan raspberries, that was harvested and packed under a new and more stringent system, was allowed to be imported into Canada. Health Canada and the Canadian Food Inspection Agency are currently reviewing the importation policy for the spring crop (April and June) of Guatemalan raspberries and blackberries (personal communication, René Cardinal, Canadian Food Inspection Agency,
2000). Cyclosporiasis was made a nationally notifiable disease in Canada on January 1, 2000.

These outbreaks of cyclosporiasis in North America have established cyclospora as a foodborne pathogen and cyclosporiasis as a disease that is not restricted to travelers returning from developing countries. Laboratory diagnosis of cyclosporiasis is necessary to detect outbreaks and to differentiate the clinical presentation from that seen with other enteric pathogens. In addition, specific medical treatment (ie, with trimethoprim/sulphamethoxazole [3]) is available once cyclosporiasis is diagnosed.

In the past, foodborne outbreaks were often thought of as local events, affecting a group of people eating at a restaurant or attending a social event (15). With globalization of food products, the impact of foodborne outbreaks is also globalized. Local, national and international organizations and agencies need to work closely together to strengthen global surveillance and the capacity to control, and prevent, future outbreaks (15). The investigation of this international outbreak of cyclosporiasis in 1996 demonstrated the importance of a coordinated, multijurisdictional public health response.

ACKNOWLEDGEMENTS: The authors thank Mariana Grmusa and Wayne Lee, Public Health Inspectors, North York Health Department, Toronto, Ontario; Doug Morrison, Mary Anne Rose and Jeff Wilson, Health Canada, Ottawa, Ontario; Maria Arrieta, Montreal Children's Hospital, Montreal, Quebec; Michael Brodsky and T Scholten, Ontario Ministry of Health, Toronto, Ontario; Brian Ward, Montreal General Hospital, Montreal, Quebec; John Carsley, Montreal Public Health Department, Montreal, Quebec; Idera Rusen, Community Medicine Resident, University of Toronto, Toronto, Ontario; Michael Arrowood and Susanne Wahlquist, Division of Parasitic Diseases, National Center for Infectious Diseases, Centers for Disease Control and Prevention, Atlanta, Georgia, for their invaluable support during the cyclosporiasis investigations.

\section{REFERENCES}

1. Ashford RW. Occurrence of an undescribed coccidian in man in Papua New Guinea. Ann Trop Med Parasitol 1979;73:497-500.

2. Pape WJ, Verdier RI, Boncy M, Boncy J, Johnson WD Jr. Cyclospora infection in adults infected with HIV. Clinical manifestations, treatment and prophylaxis. Ann Intern Med 1994;121:654-7.

3. Hoge CW, Shlim DR, Ghimire M, et al. Placebo-controlled trial of cotrimoxazole for cyclospora infections among travelers and foreign residents in Nepal. Lancet 1995;345:691-3. [Erratum, Lancet 1995;345:1060]

4. Garcia LS, Bruckner DA. Diagnostic Medical Parasitology, 3rd edn. Washington: American Society for Microbiology, 1997:66-9.

5. Huang P, Weber JT, Sosin DM, et al. The first reported outbreak of diarrheal illness associated with cyclospora in the United States. Ann Intern Med 1995;123:409-14.

6. Rabold JG, Hoge CW, Shlim DR, Kefford C, Rajah R, Echeverria P. Cyclospora outbreak associated with chlorinated drinking water. Lancet 1994;344:1360-1.

7. Herwaldt BL, Ackers ML,. An outbreak in 1996 of cyclosporiasis associated with imported raspberries. The Cyclospora Working Group. N Engl J Med 1997;336:1548-56.

8. Purych DB, Perry IL, Bulawka D, Kowalewska-Grochowska KT, Oldale BL. A case of cyclospora infection in an Albertan traveller. Can Commun Dis Rep 1995;21:88-91.

9. Brennan MK, MacPherson DW, Palmer J, Keystone JS. Cyclosporiasis: a new cause of diarrhea. CMAJ 1996;155:1293-6. 10. Manuel DG, Shahin R, Lee W, Grmusa M. The first reported 
cluster of food-borne cyclosporiasis in Canada. Can J Pub Health 1999;90:399-402.

11. Herwaldt BL, Beach MJ. The return of cyclospora in 1997: Another outbreak of cyclosporiasis in North America. Cyclospora Working Group. Ann Intern Med 1999;130:210-20.

12. Centers for Disease Control and Prevention. Outbreak of cyclosporiasis - Northern Virginia-Washington, DC-Baltimore, Maryland, metropolitan area, 1997. MMWR Morb Mortal Wkly Rep 1997;46:689-91.
13. Outbreak of cyclosporiasis - Ontario, May 1998. Can Commun Dis Rep 1998;24:153-6.

14. Buck P, Huang S, Pichette S, et al. Raspberries and cyclospora: not a berry healthy combination! International Clinical Epidemiology Network (INCLEN) XVI Global Meeting. March date, 1999, Bangkok, Thailand.

15. Tauxe RV, Hughes JM. International investigation of outbreaks of foodborne disease. BMJ 1996;313:1093-4

\title{
CLINICAL VIGNETTE
}

\section{Forearmed and deceived: Diagnosis?}

\author{
LJ Miedzinski $M D^{1}$, J Mahood $M D^{2}, M \operatorname{Sin} M B B^{3}, G$ Sterling $M D^{3}$
}

A 58-year-old male with a four-year history of noninsulin dependent diabetes presented in early January 1999 with a two-week history of progressive right forearm swelling, pain, and limitation of wrist and elbow movement unassociated with recognized trauma. He had been febrile in the three days before the evaluation, despite having been on an antiinflammatory medication for approximately one week. Progressive clinical worsening in association with a markedly elevated erythrocyte sedimentation rate prompted referral to an infectious diseases consultant regarding the possibility of osteomyelitis.

On examination, the patient was flushed, tachycardic at 110 beats/min and mildly febrile, with a temperature of $38.2^{\circ} \mathrm{C}$. Blood pressure was $150 / 90 \mathrm{mmHg}$ in the right arm sitting. Physical examination revealed no conjunctival petechiae, normal heart sounds and specifically no cardiac murmurs. The most relevant physical abnormality was an indurated right forearm, edematous from the elbow to the metacarpophalangeal joints of the hand. There was minimal erythema over the dorsum of the hand and wrist, and no deep tenderness to palpation of the muscles. Although there was no limitation to passive movements of either wrist or elbow, there was marked limitation of active wrist and elbow extension.
White blood count was elevated at $17.0 \times 10^{9} / \mathrm{L}$, with a normal hemoglobin of $142 \mathrm{~g} / \mathrm{L}$ and platelet count of $295 \times 10^{9} / \mathrm{L}$. Creatinine was normal at $77 \mathrm{~mol} / \mathrm{L}$ with a normal creatine $\mathrm{ki}$ nase of $58 \mathrm{U} / \mathrm{L}$. The random glucose level was elevated to 16.5 $\mathrm{mmol} / \mathrm{L}$. An X-ray of the arm showed no gas in the soft tissues nor any changes suggestive of osteomyelitis.

Because of the possibility of group A streptococcal fasciitis, an orthopedic evaluation was requested. The surgeon felt confident that the patient did not have compartment syndrome nor did he think invasive fasciitis was likely. Blood cultures were obtained, and the patient was started on empirical intravenous clindamycin and ceftriaxone.

By the next day, the patient's blood cultures were reported positive for Staphylococcus aureus, resistant to penicillin but sensitive to oxacillin. A bone scan showed diffuse hyperemia of the forearm "consistent with an inflammatory condition such as cellulitis" and no evidence of osteomyelitis. The patient's antibiotics were changed to intravenous cloxacillin. Over the next three days, the patient showed little change in the appearance or discomfort of his arm despite a decreasing fever and decreasing leukocytosis.

A diagnostic procedure was performed. What is your diagnosis?

continued on page 102

\footnotetext{
${ }^{1}$ Division of Infectious Diseases, ${ }^{2}$ Division of Orthopedic Surgery and the ${ }^{3}$ Department of Radiology, University of Alberta, Edmonton, Alberta Correspondence and reprints: Dr L Miedzinski, Division of Infectious Diseases, WMC 2E4.11, University of Alberta, 8440 - 112 Street, Edmonton, Alberta T6G 2B7. Telephone 780-407-7313, fax 780-407-7137, e-mail lil.miednzinski@ualberta.ca
} 


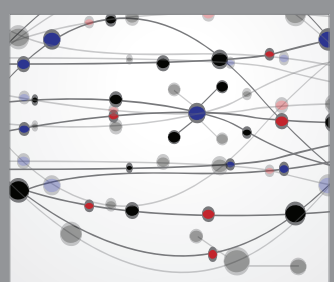

The Scientific World Journal
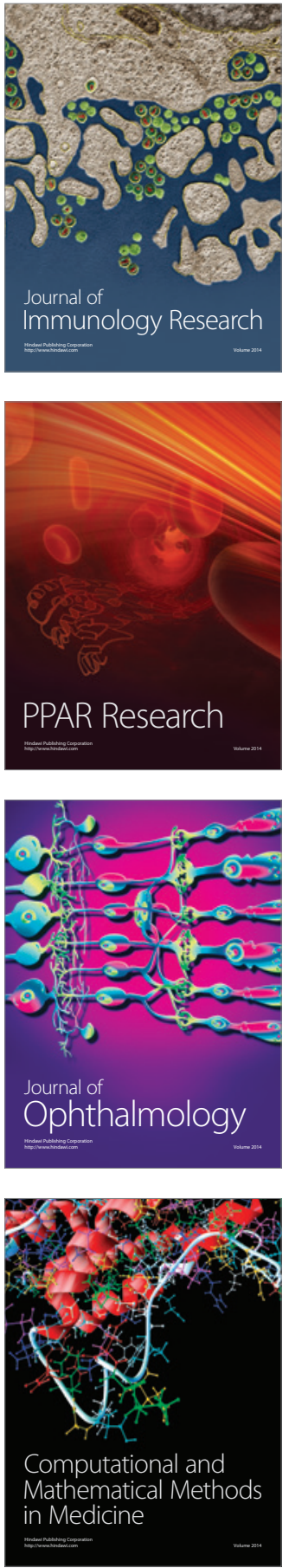

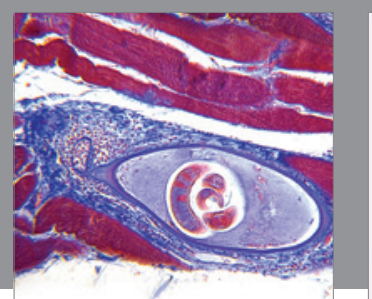

Gastroenterology Research and Practice

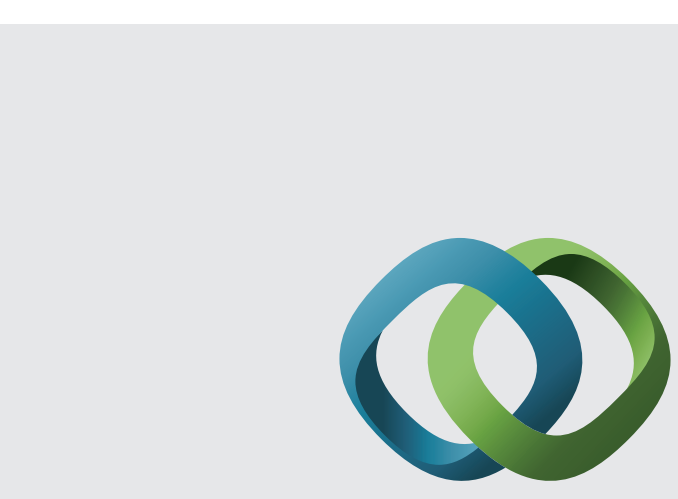

\section{Hindawi}

Submit your manuscripts at

http://www.hindawi.com
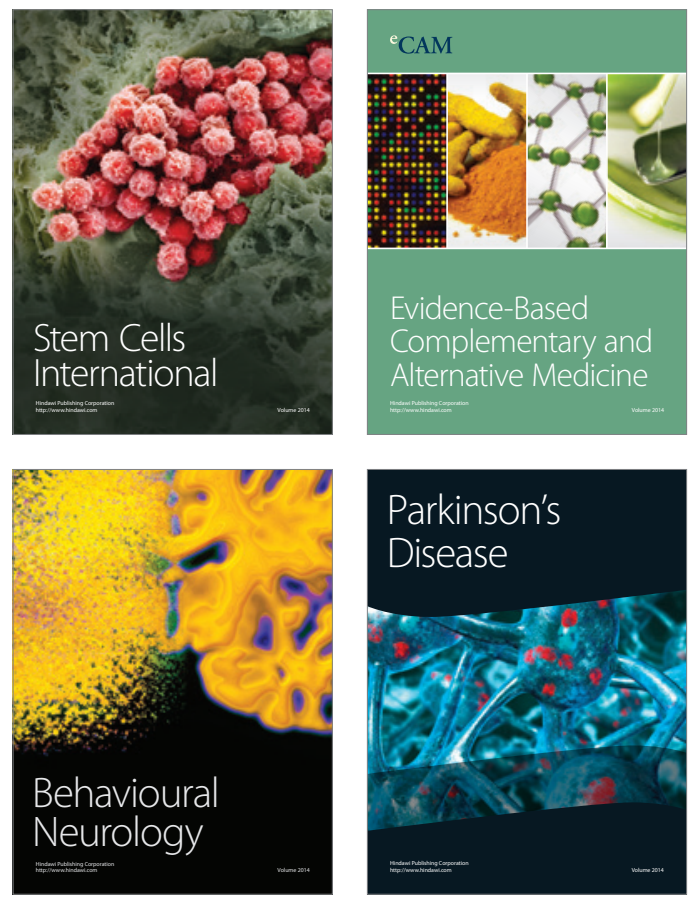
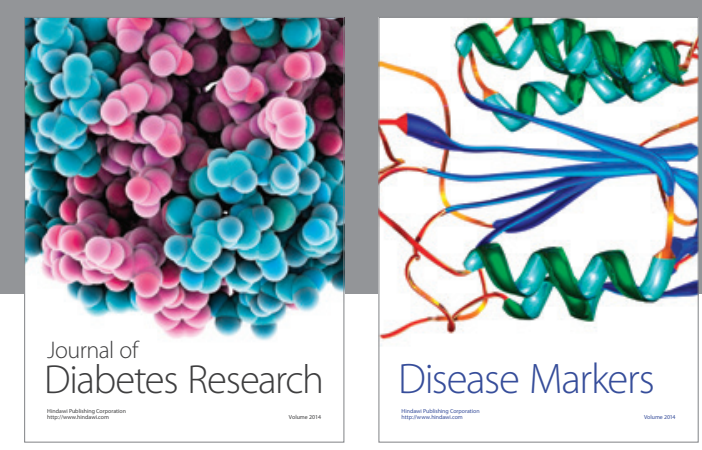

Disease Markers
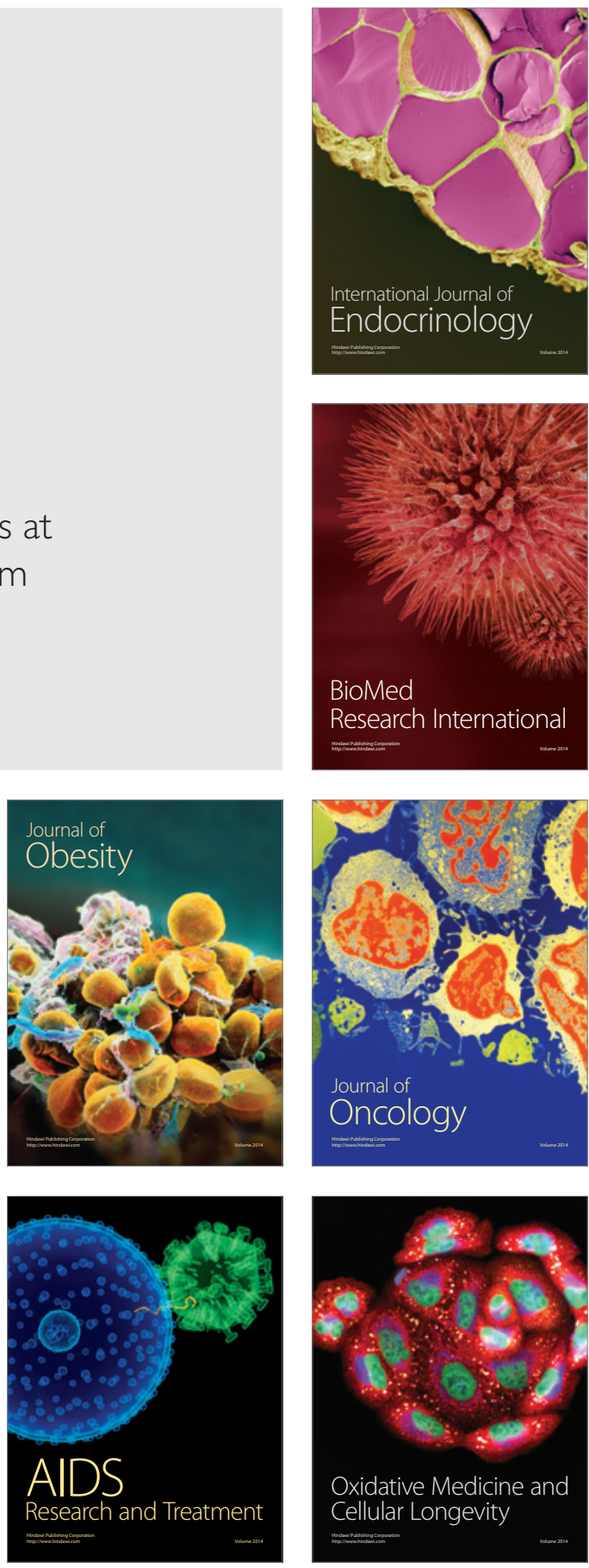